\title{
The Innovation Leadership through Mapping with HRIS towards Sustainability Development Goals
}

\author{
Dian Ambarwati, Gidiono Tirtoadisurja \\ Management Department \\ Sekolah Tinggi Ilmu Ekonomi IEU \\ Surabaya, Indonesia \\ dian.ambarwati@ieu.ac.id \\ gidiono@ieu.ac.id
}

\begin{abstract}
Leadership is art to influence other people to reach goals together through directing, motivate, supervising, ordering and guiding. Successfully leadership depend on how many people to lead through empowering employee to maximize ability potential. For to know ability potential employee done mapping human resources management. Mapping human resources management is knowing potential employee so leader will be develop based on potential in order to increase their quality. Mapping is very important to continuous analysis and then development human resources management can use HRIS (human resources information system). Development human resources management part of sustainability development goals (SDGs). In the SDGs combines all aspect to reach goals. This research use qualitative analysis. Collective data from literature review, internet and interview. Result from this research is find innovation leadership through mapping in order to development employee in the organization with human resources information system towards sustainability development goals. Conclusion from the research is importance innovation leadership through mapping, because human resource very important so must be developed. The high quality human resources a country showing quality country.
\end{abstract}

Keywords: Innovation leadership, Human Resources, Mapping, HRIS and SDGs

\section{INTRODUCTION}

Innovation is the process of translating an idea or invention into a good or service that creates value or for which customers will pay. To be called an innovation, an idea must be replicable at an economical cost and must satisfy a specific need. Innovation involves deliberate application of information, imagination and initiative in deriving greater or different values from resources, and includes all processes by which new ideas are generated and converted into useful products. In business, innovation often results when ideas are applied by the company in order to further satisfy the needs and expectations of the customers. For to reach success in business need innovation leadership because they need it for themselves as they learn to operate in challenging, unpredictable circumstances. They also need to create a climate for innovation within organizations. Leadership very important. Leadership is art to influence other people to reach goals together through directing, motivate, supervising, ordering and guiding [1]. Successfully leadership depend on how many people to lead through empowering employee to maximize ability potential. For to know ability potential employee done mapping human resources management with combine

There are two component on leadership innovation. The first an innovative approach to leadership. This means to bring new thinking and different actions to how you lead, manage, and go about your work. How can you think differently about your role and the challenges you and your organization face? What can you do to break open entrenched, intractable problems? How can you be agile and quick in the absence of information or predictability? The second Leadership for innovation. Leaders must learn how to create an organizational climate where others apply innovative thinking to solve problems and develop new products and services. It is about growing a culture of innovation, not just hiring a few creative outliers. How can you help others to think differently and work in new ways to face challenges? What can be done to innovate when all resources are stressed and constrained? How can you stay alive and stay ahead of the competition? This two-tiered approach generates the kind of innovation that can produce the next new product or design, but it goes well beyond. Innovative leadership - the use of innovative thinking and the leadership that supports it-is the key to finding what's new, what's better, and what's next. Applying innovative thinking to your challenges as a leader is one step in creating an innovative, organizational response to change and challenge. But developing a culture of innovation, where others throughout the organization apply innovative thinking to solve problems and develop new products and services, requires additional work [1].

Human resources management is a central factors hearts an organization as well better resources management hearts achieve the objective of the organization and that the employee is an asset largest hearts an organization as well, so that assets can be in protect with goal organization and must provide comfort hall hearts work. Notoatmojo (2003) suggested the prayer man as one component resources organization as well as a determinant of achievement of the vision and mission of the organization. 
Mapping human resources management is knowing potential employee so leader will be develop based on potential in order to increase their quality. Mapping is very important to continuous analysis and then development human resources management can use HRIS (human resources information system). Development human resources management part of sustainability development goals (SDGs). In the SDGs combines all aspect to reach goals.

Process Mapping allows a true buy - in to the completed product. Maps are developed in real time, and the employee can see exactly what is being recorded. They are developed in an interactive atmosphere that allows the employee to physically change what is occurring. Plus, it allows them to provide input on where the system can be improved. In our experience, we have gone back to offices where employees were excited about the process. They told new employees about the review that was going to be completed and looked forward to their turn to talk to us. Process Mapping not only provides management with an overall view of operations, but also provides employees with a view of how their work adds value and how they are part of a team. The holistic approach allows them to see where their work comes from. They can see the steps that lead to the product they receive and understand the work that has gone before. They can also see why they are doing what they do. Each step in the process should lead to further steps in the map. Eventually, this should lead to a final benefit to the customer. Process Mapping is often the first time employees understand why they are doing the work they do. It helps them understand why a bothersome statistic they are required to generate is important to a report that drives future customer transactions. Or it may show why they should not use a certain code they thought would make things run smoother [2].

Event management human resources management good very dependent on quality review information for decision making in the field of human resources. The ability of the organization as well as the hearts acquiring, storing, maintaining and using information of human resources are important factors that support the sustainability of Life Company. Should companies realize the importance of human resource fulfilment operations quality and the right to keep to review developed human resources information systems to review support the fulfilment of the human resources quality, system singer the name is commonly called HRIS (Human Resources Information System). HRIS (Human Resources Information System) is a support system for decision-making process management with availability of different information takes as information needs employee / employees is high, the recruitment system, information employee data, information management employees up regarding the dismissal of an employee information. Human resource information systems (HRIS) is an integration of human resource management (HRM) and Information Technology (IT).

Sustainable development goals is the process reach goals amount 17 with no poverty, zero hunger, good health and well-being, quality education, gender quality, clean water and sanitation, affordable and clean energy, decent work and economy growth, industry innovation and infrastructure, reduced inequality, sustainable cities and communities, responsible consumption and production, climate action, life below water, life on land, peace justice and strong institution, partnership for the goals [3].

\section{DATA AND METHODS}

The qualitative research results more emphasis on meaning that generalizations in general the reason using qualitative method because it is not yet clear, problem, holistic, complex, dynamic and full of meaning so there may be not possible to gathered data on social situation by the quantitative method research by instrument such as questionnaire test, interview guidelines. This research was survey research with descriptive design for aiming to find out the descriptive of causal mapping human resources management through human resources information system (HRIS). The location research of this research was public university, private university and Company all East Java with amount 836 .

\section{RESULT AND DISCUSSION}

Mapping is the general definition graphical representative procedure, process, structure or system that depict arrangement of a relationship among its different component and traces flow energy, goods, information, materials, money, etc. in the mapping human resources management will be found as follow there is an absence of agreed staffing standards and staffing structures that are partially funded and cumbersome to update.

Insufficient collaborative decision-making related to planning and development of all sector worker training leads to a mismatch between numbers of staff required in a given cadre and the number being trained.

Decentralized responsibility for certain aspects of human resources management in the all sector makes it difficult to assure adequate human resources for all sector across the country. Complexities in the recruitment process create a variety of delays in filling of vacant posts.

A number of issues hinder the planning, budgeting and expenditure of funds in the most effective manner. Unclear and/or unenforced standards for health worker performance erode the quality of care and service provided.

Limited capacity for management and leadership of the health system makes it difficult for managers and supervisors to make best use of the limited resources they have. 
TABLE I. WORLD BANK INDICATORS - INDONESIA - ECONOMY ACTIVITY

\begin{tabular}{|c|c|c|c|c|}
\hline Description & 1990 & 2000 & 2010 & 2014 \\
\hline $\begin{array}{l}\text { Employees; agriculture; female (\% of female } \\
\text { employment) in Indonesia }\end{array}$ & 56.3 & 46.7 & 38.0 & \\
\hline $\begin{array}{l}\text { Employees; agriculture; male (\% of male } \\
\text { employment) in Indonesia }\end{array}$ & 55.6 & 44.4 & 39.0 & \\
\hline $\begin{array}{l}\text { Employment in agriculture (\% of total } \\
\text { employment) in Indonesia }\end{array}$ & 55.9 & 45.3 & 38.3 & \\
\hline $\begin{array}{l}\text { Employment to population ratio; ages } 15-24 \\
\text { female }(\%) \text { in Indonesia }\end{array}$ & & 35.7 & 30.6 & 31.2 \\
\hline $\begin{array}{l}\text { Employment to population ratio; ages } 15-24 \\
\text { male }(\%) \text { in Indonesia }\end{array}$ & & 54.6 & 48.9 & 47.2 \\
\hline $\begin{array}{l}\text { Employment to population ratio; ages } 15-24 \\
\text { total }(\%) \text { in Indonesia }\end{array}$ & & 45.2 & 39.9 & 39.3 \\
\hline $\begin{array}{l}\text { Share of women employed in the nonagricultural sector } \\
\text { (\% of total nonagricultural employment) in Indonesia }\end{array}$ & 29.2 & 31.7 & & \\
\hline $\begin{array}{l}\text { Employment to population ratio; } 15+\text {; female } \\
(\%) \text { in Indonesia }\end{array}$ & & 47.1 & 46.6 & 47.7 \\
\hline $\begin{array}{l}\text { Employment to population ratio; } 15+; \text { male } \\
(\%) \text { in Indonesia }\end{array}$ & & 79.8 & 79.0 & 79.4 \\
\hline $\begin{array}{l}\text { Employment to population ratio; } 15+; \text { total } \\
(\%) \text { in Indonesia }\end{array}$ & & 63.3 & 62.6 & 63.5 \\
\hline
\end{tabular}

Based on table I showing that total employment to population ration in Indonesia there is decreasing in agricultural and increasing non-agricultural sector. This give influence economy sector in Indonesia. There is improving on non-agricultural sector.

TABLE II. DATA OF PRIVATE UNIVERSITY IN EAST JAVA

\begin{tabular}{|c|c|c|c|c|}
\hline No & Category & Amount & Area & Notes \\
\hline 1 & University & 3 & Banyuwangi & I \\
\hline 2 & Institute & 25 & Surabaya & II \\
\hline 3 & High School & 1 & Situbondo & III \\
\hline 4 & Polytechnics & 3 & Bojonegoro & IV \\
\hline 5 & Academy & 1 & Bondowoso & $\mathrm{V}$ \\
\hline 6 & & 16 & Madiun & VI \\
\hline 7 & & 12 & Jombang & VII \\
\hline 8 & & 44 & Malang & VIII \\
\hline 9 & & 12 & Jember & IX \\
\hline 10 & & 5 & Blitar & $X$ \\
\hline 11 & & 5 & Lamongan & XI \\
\hline 12 & & 4 & Gresik & XII \\
\hline 13 & & 18 & Kediri & XIII \\
\hline 14 & & 3 & Madura & XIV \\
\hline 15 & & 10 & Mojokerto & $\mathrm{XV}$ \\
\hline 16 & & 11 & Sidoarjo & XVI \\
\hline 17 & & 5 & Lumajang & XVII \\
\hline 18 & & 10 & Pasuruan & XVIII \\
\hline 19 & & 4 & Ponorogo & XIX \\
\hline 20 & & 5 & Probolinggo & XX \\
\hline 21 & & 6 & Tuban & XXI \\
\hline 22 & & 3 & Ngawi & XXII \\
\hline
\end{tabular}

\begin{tabular}{|l|l|l|l|l|}
\hline \multicolumn{2}{|l|}{ (Table II, cont.) } & \multicolumn{2}{l|}{} \\
\hline 23 & 2 & Sumenep & XXIII \\
\hline 24 & & Caruban & XXIV \\
\hline 25 & & 1 & Trenggalek & XXV \\
\hline 26 & & 3 & Tulungagung & XXVI \\
\hline 27 & & 2 & Sampang & XXVII \\
\hline 28 & & Pacitan & XXVIII \\
\hline 29 & & Kertosono & XXIX \\
\hline 30 & & Bangkalan & XXX \\
\hline
\end{tabular}

Based on table II, there is 30 private university in East Java with Classification University, institute, high school, polytechnic and academy.

TABLE III. DATA OF PRIVATE UNIVERSITY IN EAST JAVA

\begin{tabular}{|c|c|c|c|c|}
\hline No & Category & Amount & Area & Notes \\
\hline 1 & University & 4 & Malang & I \\
\hline 2 & Institute & 3 & Jember & II \\
\hline 3 & High School & 6 & Surabaya & III \\
\hline 4 & Academy & 1 & Kediri & IV \\
\hline 5 & & 1 & Madiun & V \\
\hline 6 & & 1 & Pamekasan & VI \\
\hline 7 & & 1 & Banyuwangi & VII \\
\hline 8 & & 1 & Ponorogo & VIII \\
\hline 9 & & 1 & Madura & IX \\
\hline 10 & & 1 & Tulungagung & X \\
\hline
\end{tabular}

Based on table III showing that there is 10 private university in East Java with Classification University, institute, high school and academy.

TABLE IV. DATA OF COMPANY IN EAST JAVA

\begin{tabular}{|c|c|c|c|c|}
\hline No & Category & Amount & Area & Notes \\
\hline 1 & Service & 75 & Surabaya & I \\
\hline 2 & Manufacture & 55 & Pasuruan & II \\
\hline 3 & Goods & 39 & Sumenep & III \\
\hline 4 & Small Industry & 10 & Jombang & IV \\
\hline 5 & Variety Industry & 38 & Gresik & $\mathrm{V}$ \\
\hline 6 & & 8 & Blitar & VI \\
\hline 7 & & 9 & Tulungagung & VII \\
\hline 8 & & 30 & Malang & VIII \\
\hline 9 & & 55 & Sidoarjo & IX \\
\hline 10 & & 4 & Trenggalek & $\mathrm{X}$ \\
\hline 11 & & 21 & Tuban, & XI \\
\hline 12 & & 3 & Batu & XII \\
\hline 13 & & 18 & Banyuwangi & XIII \\
\hline 14 & & 12 & Probolinggo & XIV \\
\hline 15 & & 8 & Kediri & $\mathrm{XV}$ \\
\hline 16 & & 8 & Situbondo & XVI \\
\hline 17 & & 29 & Mojokerto, & XVII \\
\hline 18 & & 4 & Bondowoso & XVIII \\
\hline 19 & & 2 & Sampang & XIX \\
\hline 20 & & 2 & Bojonegoro & XX \\
\hline 21 & & 11 & Lamongan & XXI \\
\hline 22 & & 11 & Lumajang & XXII \\
\hline 23 & & 20 & Jember & XXIII \\
\hline 24 & & 3 & Bangkalan & XXIV \\
\hline
\end{tabular}


Based on table IV showing 24 private company in East Java with classification service, manufacture, goods, small industry and industry variety.

Management Information Systems Human Resources (HRIS) is a support system of management decision-making process with the availability of the necessary information such as the information needs of employees, recruitment system, employee data information, employee information management to information regarding the dismissal of employees. Human Resource Information Systems (HRIS) is the integration of human resource management (HRM) and information technology (IT). This system combines HRM as a discipline that primarily apply information technology into the activities of HRM as in planning and preparing the data processing system in a series of steps are standardized and summarized in the application of enterprise resource planning/enterprise resource planning (ERP). In principle HRIS implementation in the organization/company will make it easier for organizations to manage its human resources systematically so that HR data will be managed properly.

In the Human Resource Information System (HRIS) entered data is data staffing system that includes processes processes such as: Human Resource Planning, Personnel Administration, Payroll, Compensation and Benefit, Personnel Performance, Education and Training and Termination / Retirement

Benefits of implementing Human Resource Information System (HRIS) is : facilitate the capability Checking employees to fill the vacancy on a part / position, to describe specific jobs or job classes that have this level of turnover, absenteeism, performance and high problems that exceed normal levels, guidelines for the recruitment, selection, training and development of employees so that no one in the position of employees / right man in the right place, facilitate the planning system and development of employees for the career system, facilitate reporting system related issues concerning compensation system employee payroll system problems and other benefits earned by the employees and as a reference to employee training needs assessment to analyse the work of individual employees and determine which ones need further training.

The current generation of HRIS automates and devolves routine administrative and compliance functions traditionally performed by corporate HR departments and can facilitate the outsourcing of HR. More recent research shows greater use of HRIS in support of strategic decision making by HR. With an appropriate HRIS, HR staff enables employees to do their own benefits updates and address changes, thus freeing HR staff for more strategic functions. Additionally, data necessary for employee management, knowledge development, career growth and development, and equal treatment are facilitated. Finally, managers can access the information they need to legally, ethically, and effectively support the success of their reporting employee. Human resources information system will help to create human resources competence. This is will help the success of the program Sustainable Development Goals (SDGs) that Indonesian part of these country.

The new set of goals, the Sustainable Development Goals (SDGs), aims to end poverty and hunger by 2030 . World leaders, recognizing the connection between people and planet, have set goals for the land, the oceans and the waterways. The world is also better connected now than it was in 2000, and is building a consensus about the future we want. The goals of sustainable development as follow: no poverty, zero hunger, good health and well-being, quality education, gender quality, clean water and sanitation, affordable and clean energy, decent work and economy growth, industry innovation and infrastructure, reduced inequality, sustainable cities and communities, responsible consumption and production, climate action, life below water, life on land, peace justice and strong institution and partnership for the goals.

\section{CONCLUSION}

Based on result discussion, researcher take conclusion as innovation leadership will help create result of decision making in condition unpredictable because the leader need innovation leadership to success in business, mapping human resources management will help organization to give value added for employee become part of the organization, human resources information system give organization to result strategic decision making, sustainable development goals have 17 goal to be reach by countries as no poverty so achieve welfare and innovation leadership through mapping human resources with human resources information system will support to success sustainable development goals.

\section{ACKNOWLEDGMENT}

The researcher say thanks for everyone that give me support, help and anything in order to this research can implemented, success and give benefit for all everyone.

\section{REFERENCES}

[1] Davod Horth, How to Use Innovation to Lead Effectively Work Collaboratively And Drive Results, Center for Creative leadership and Buchner - Continuum

[2] USAID, Mapping the Human Resources Management. America: 2008

[3] UNDP. (-). Sustainable Development Goals. America: United Nation

[4] Nn. Economic, apps. Retrieved from www.tradingeconomic.com. 2016 March.

[5] nn. (n.d.). тепи.

[6] Shiri, S. Effectiveness of Human Resource Information System on HR. US-China Education Review A 9 (2012) 830-839, 10. 